\title{
Application of Neutral Detergent-Cellulase System to the Detailed Analysis of the Changes in Digestibility of Orchardgrass During Growth
}

Akira ABE

National Institute of Animal Industry, Chiba-shi 280

(Received May 9, 1978)

\begin{abstract}
A method consisting of the successive treatments with neutral detergent and with cellulase was applied to the samples of orchardgrass hay. Dry matter of the grass was divided into two fractions, cellular contents and cell wall, in the first step. In the second step, cell wall was divided into two fractions, " $a$ " and " $b$ ", by cellulase hydrolysis. Fraction " a", which seemed to be independent of lignification and showed high digestibility, was decreased gradually as the grass matured. Fraction " $b$ ", which seemed to be covered with lignin and of lower digestibility than fraction "a", was increased in cell wall on the other hand. There was no significant correlation between the amounts of cell wall and that of digestible cell wall in dry matter, but highly significant correlations $(\mathrm{P}<0.01)$ were found between the total amount and the quantity of digestible parts of both fractions, " $a$ " and " $b$ ".

Jap. J. Zootech. Sci., 50 (1): 28-34, 1979
\end{abstract}

In a previous paper"), the following information was obtained: Cell wall (CW) of grass hay was divided into two fractions, " $a$ " and " $b$ ", by the neutral detergent and cellulase treatments. Fraction " a", which was hydrolysed rapidly by cellulase compared with fraction " $\mathrm{b}$ ", showed high apparent digestibility, $91 \%$ in average, in digestion trials with sheep.

Whereas the digestibility of fraction " $b$ " was $50 \%$ in average. On the other hand, in former times, the author investigated the changes in the nutritive value with the developing maturity of orchardgrass, first growth and regrowth, and its experimental results were already reported in this journal ${ }^{2}$. In that report ${ }^{2}$, the relationships between the changes in lignin plus silica contents during growth and the changes in the amounts of digestible dry matter (DDM) and TDN were discussed mainly. In the experiment described here, the auther tried detailed analysis of the cell wall regarding the changes in digestibility and of the changes in the amount of DDM with plant maturity of the samples used in earlier experiment ${ }^{2}$ by the method of neutral detergent and cellulase digestion based upon the concept of fraction " $a$ " and " $b$ ".

\section{Materials and Methods}

Seven orchardgrass hay samples which were prepared by suncured condition in Hokkaido Agricultural Experiment Station in 1972 ${ }^{2}$ were used for the experiment. Digestion trials of these hays were carried out with sheep in earlier experiment ${ }^{2)}$ and 
those feces were subjected to chemical analysis together with hays. The samples were treated with neutral detergent solution ${ }^{3)}$ and dry matter (DM) was divided into $\mathrm{CW}$ and cellular contents (CC). In this experiment, sodium sulfite was not added. Successive treatments with neutral detergent and cellulase were carried out as follows; the samples equivalent to $0.3 \mathrm{~g}$ of $\mathrm{CW}$ were treated with the neutral detergent solution at the first step. Residual matter, that is $\mathrm{CW}$, was washed with water, acetone, water and acetate buffer ( $\mathrm{pH} \mathrm{4.0)}$, successively, and was hydrolysed by $1.0 \%$ cellulase (Cellulase Onozuka $\mathrm{P}-1500$, isolated from Torichoderma viride) for 4 hours at $40^{\circ} \mathrm{C}$, at the second step. The soluble fraction which was determined by 4 hour cellulase hydrolysis was designated as fraction " a". Fraction " $b$ " caluculated by subtracting fraction "a" from total CW. Lignin was determined by the successive treatments with acid detergent and $72 \%$ sulfuric acid ${ }^{4,5)}$. In this experiment, the data such as contents or digestibilities or digestible amounts of $\mathrm{DM}$ and $\mathrm{CW}$ of hays were quoted from a former paper's.

\section{Results and Discussion}

Table 1 shows the amounts of $\mathrm{CC}, \mathrm{CW}$, fraction " $\mathrm{a}$ " fraction " $\mathrm{b}$ " and lignin of seven orchardgrass hays. Lignin contents increased gradually as the grass matured. In the first growth, the level of fraction " $a$ " in CW was decreased and that of fraction " $b$ " was increased during growth. In former report ${ }^{2)}$, it was discussed that total CW contents were increased gradually as the grass matured. Lignin contents in DM increased significantly $(r=0.942, \mathrm{P}<0.01)$ in proportion to the increase of $\mathrm{CW}$.

It is generally accepted that the amounts of DDM decrease with in the course of

Table 1. Amounts of $\mathrm{CC}, \mathrm{CW}$, Fraction "a ", Farction " $\mathrm{b}$ " and lignin in $\mathrm{DM}, \mathrm{CW}$ or Fraction " $\mathrm{b}$ " of seven orchardgrass hays.

\begin{tabular}{|c|c|c|c|c|c|c|c|c|c|}
\hline \multirow[b]{2}{*}{ Hay } & \multirow{2}{*}{$\begin{array}{c}\mathrm{C} \mathrm{C} \\
\% \\
\mathrm{DM}\end{array}$} & \multirow{2}{*}{$\begin{array}{c}\text { CW } \\
\% \\
(\mathrm{a}) \\
\mathrm{DM}\end{array}$} & \multicolumn{2}{|c|}{$\begin{array}{c}\text { Fraction } \\
\text { "a" }\end{array}$} & \multicolumn{2}{|c|}{$\begin{array}{c}\text { Fraction } \\
\text { "b" }\end{array}$} & \multicolumn{3}{|c|}{ Lignin } \\
\hline & & & $\begin{array}{c}\% \\
\mathrm{DM}\end{array}$ & $\stackrel{\%}{\mathrm{C} W}$ & $\begin{array}{c}\% \\
\mathrm{DM}\end{array}$ & $\stackrel{\%}{\mathrm{CW}}$ & DM & $\stackrel{\%}{\mathrm{C} W}$ & " $\%$ \\
\hline \multicolumn{10}{|c|}{ First growth } \\
\hline June 1 & 49.8 & 50.2 & 27.1 & 54.0 & 23.1 & 46.0 & 2.9 & 5.8 & 12.6 \\
\hline June 13 & 41.7 & 58.3 & 24.9 & 42.7 & 33.4 & 57.3 & 3.5 & 6.0 & 10.5 \\
\hline July 3 & 34.2 & 65.8 & 20.1 & 30.5 & 45.7 & 69.5 & 6.0 & 9.1 & 13.1 \\
\hline \multicolumn{10}{|c|}{ Second growth } \\
\hline July 15 & 41.3 & 58.7 & 24.1 & 41.1 & 34.6 & 58.9 & 4. 4 & 7.5 & 12.7 \\
\hline July 24 & 41.3 & 58.7 & 20.8 & 35.4 & 37.9 & 64.6 & 4.3 & 7.3 & 11.4 \\
\hline Aug. 7 & 34.2 & 65.8 & 24.2 & 36.8 & 41.6 & 63.2 & 5.4 & 8.2 & 13.0 \\
\hline \multicolumn{10}{|c|}{ Third growth } \\
\hline Sept. 25 & 41.2 & 58.8 & 23.1 & 39.3 & 35.7 & 60.7 & 4. 2 & 7.1 & 11.8 \\
\hline Mean & & & & & & & 4. 4 & 7.3 & 12.2 \\
\hline (S. D) & & & & & & & $(1.1)$ & $(1.2)$ & $(1.0)$ \\
\hline
\end{tabular}

(a): As described previously2) 


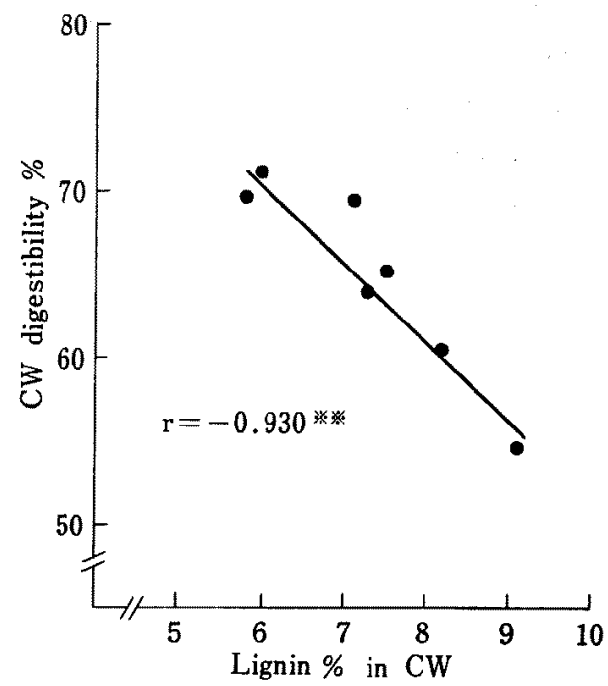

Fig. 1. Relationship between lignin content in $\mathrm{CW}$ and $\mathrm{CW}$ digestibilities of seven orchardgrass hays. $\quad \because P<0.01$

growth of forage plant ${ }^{6}$. It is noteworthy that the results mentioned above has enabld explain the decrease in DDM during growth by the following two factors; the decrease in $\mathrm{CC}$, high or complete in nutritive availability ${ }^{7}$, induced by increasing of $\mathrm{CW}$ in DM and the decrease in CW digestibility. The actual proportion of cell wall structural carbohydrates which are digested by rumen microorganisms is considered to be dependent on several factors. One of the most important matters is the stage of maturity of the plant which is closely related with lignin contents of the cell wall ${ }^{8}$. In this study, CW digestibility decreased gradually with increasing level of lignin contents in $\mathrm{CW}$ with developing maturity of plant, and there was highly significant negative correlation $(r=-0.930, P<0.01)$ between lignin contents in $\mathrm{CW}$ and $\mathrm{CW}$ digestibilities (as shown in fig. 1.). VAN SOEST reported that there was significant negative correlation, $\mathrm{r}=-0.90, \mathrm{P}<0.01$, between the $\mathrm{CW}$ digestibility and lignin contents in $\mathrm{CW}^{7)}$.

Next, it becomes a matter of great concern whether lignification of cell wall as the grass matured occurs uniformly through the cell wall or in particular parts. Cellulase hydrolysis of grass $\mathrm{CW}$ is composed of two first order reactions which are different in degree of velocity. The cell wall fraction that was hydrolysed by cellulase by the time when the reaction curve showed an inflection point-60 minutes after the start of the reaction - was defined as nonlignified or noncrystallized fraction, being named NCL region. The fraction that was obtained as the differrence between NCL and $\mathrm{CW}$ was defined as lignified and crystallized fraction, being named CL region ${ }^{1}$. The fraction " a" can be considered to be constituted almost of NCL region. The digestibility of fraction "a" of 32 samples of grass hays and cubes was $90.8 \pm 5.1 \%$ and fraction " $b$ " consisting of CL region was $49.7 \pm 9.5 \%$ in our previous experiment". 


\section{Neutral Detergent-Cellulase System to Grass}

Table 2. Digestibilities of fraction " $a$ " and " $b$ ", and the amounts of digestible $\mathrm{CC}$ and $\mathrm{CW}$ of seven orchard-grass hays.

$\%$ or $\% \mathrm{DM}$

\begin{tabular}{|c|c|c|c|c|}
\hline $\begin{array}{l}\text { Hay } \\
\text { (cutting date) }\end{array}$ & $\begin{array}{c}\text { Digesti- } \\
\text { bilities of } \\
\text { fraction "a " }\end{array}$ & $\begin{array}{c}\text { Digesti - } \\
\text { bilities of } \\
\text { fraction " } b \text { ", }\end{array}$ & $\begin{array}{l}\text { Amounts of } \\
\text { digestible } \\
\text { C C }\end{array}$ & $\begin{array}{l}\text { Amounts of } \\
\text { digestible } \\
\text { CW (a) }\end{array}$ \\
\hline \multicolumn{5}{|l|}{ First growth } \\
\hline June 1 & 92.3 & 44.3 & 35.1 & $34.8(72)$ \\
\hline June 13 & 97.7 & 49.0 & 27.6 & $41.7(58)$ \\
\hline July 3 & 84.6 & 43.9 & 18.2 & $36.1(47)$ \\
\hline \multicolumn{5}{|l|}{ Second growth } \\
\hline July 15 & 92.2 & 46.6 & 24.3 & $38.2(58)$ \\
\hline July 24 & 92.0 & 46.8 & 26.5 & $37.4(51)$ \\
\hline Aug. 7 & 90.2 & 42.6 & 17.5 & $39.7(55)$ \\
\hline \multicolumn{5}{|l|}{ Third growth } \\
\hline Sept. 25 & 95.4 & 53.4 & 24.9 & $41.1(54)$ \\
\hline Mean $\pm S . D$ & $92.1 \pm 4.1$ & $46.7 \pm 3.7$ & $24.9 \pm 6.0$ & $38.4 \pm 2.6$ \\
\hline
\end{tabular}

Table 2 shows the digestibilities of two fractions of $\mathrm{CW}$ of seven orchardgrass hays. Digestibilities of fraction " $a$ " and " $b$ " in this experiment were 92.1 \pm 4.1 and $46.7 \pm$ $3.7 \%$, respectively. Highly significant correlation ( $\mathrm{r}=0.948, \mathrm{P}<0.01$ ) was obtained between the amounts of fraction " $b$ " in DM and the amounts of lignin in DM. The lignin contents in fraction " $b$ " showed smaller variation, coefficient of variation being 8.2\%, than lignin contents in $\mathrm{CW}$, coefficient of variation being $16.4 \%$. From these results, it is considered that fraction " $b$ " is of uniform structure with regard to lignification compared with whole cell wall tissue.

It is evident that the fraction which is hydrolysed by cellulase was easily digested by microorganisms in the rumen and fraction " a" may be a useful portion of carbohydrates in feeds next to available carbohydrates such as mono, oligo-saccharides, fructosan and starch.

The percentages in CW of fraction "a" which is independent of lignification decreased, while that of fraction " $b$ " which is covered with lignin, and has lower digestibility than fraction " $a$ ", increased as the components of $\mathrm{CW}$ with developing maturity of plant. Influenced by the relative amounts of fraction " $a$ " and " $b$ " in $\mathrm{CW}, \mathrm{CW}$ digestibility may change according to the stage of maturity. When a forage plant is in early stage of growth, being less lignified, the amount of fraction "a" in CW is fairly large as compared with that of fraction " $b$ " and the digestible portion of fraction " a" occupies the major part of digestible $\mathrm{CW}$, as is evident from table 2.

Wherease, during a course of maturity, the digestible portion of $\mathrm{CW}$ shifts to digestible fraction " $b$ ". This is remarkable in the case of first growth, resulting in a small variation in the amounts of digestible $\mathrm{CW}(38.4 \pm 2.6 \%)$ than the amounts of 

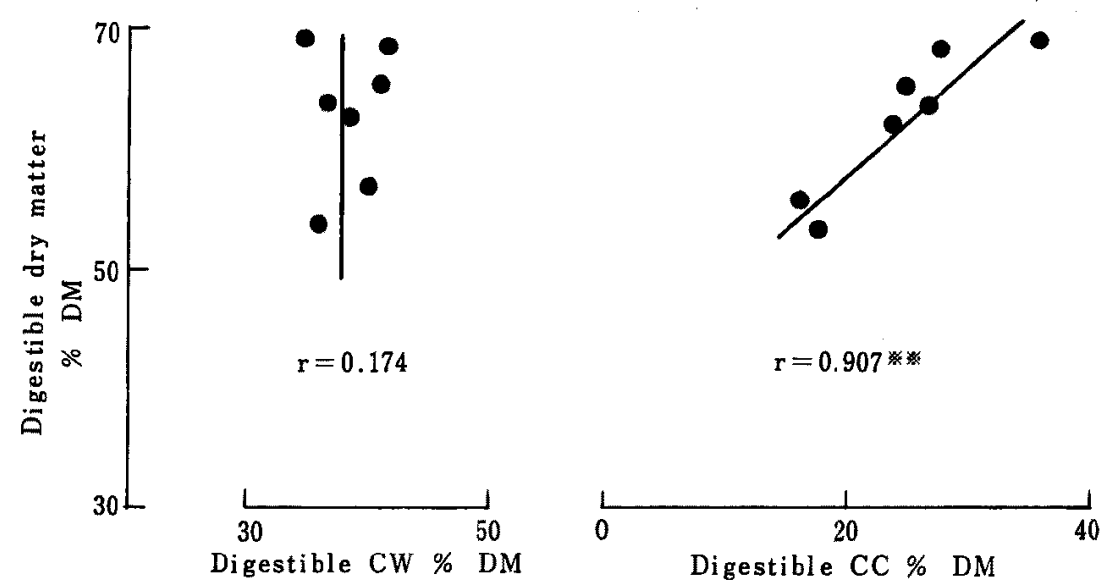

Fig. 2. Correlations of digestible dry matter with the amounts of digestible $\mathrm{CW}$ and digestible $\mathrm{CC} . \quad$ * $* 0.01$

digestible CC. DDM is composed of digestible $\mathrm{CC}$ and digestible $\mathrm{CW}$. Fig. 2 shows the correlations of DDM with the amounts of digestible $\mathrm{CC}$ and digestible $\mathrm{CW}$. From two correlation coefficients, as shown in fig. 2, it is considered that the change in DDM is influenced apparently by the amounts of digestible CC. As in the results obtained by VAN SoEST ${ }^{7}$, CC fraction has nutritive uniformity, and the amounts of digestible $\mathrm{CC}$ strongly correlated to the contents of $\mathrm{CC}$ in DM.

According to this relationship, the fact that the change in DDM is influenced apparently by the digestible CC can say as follows; DDM of orchardgrass hay is influenced mainly by the contents of CC in DM itself.

Figures 3 and 4 show the correlations between total amounts and the quantities of
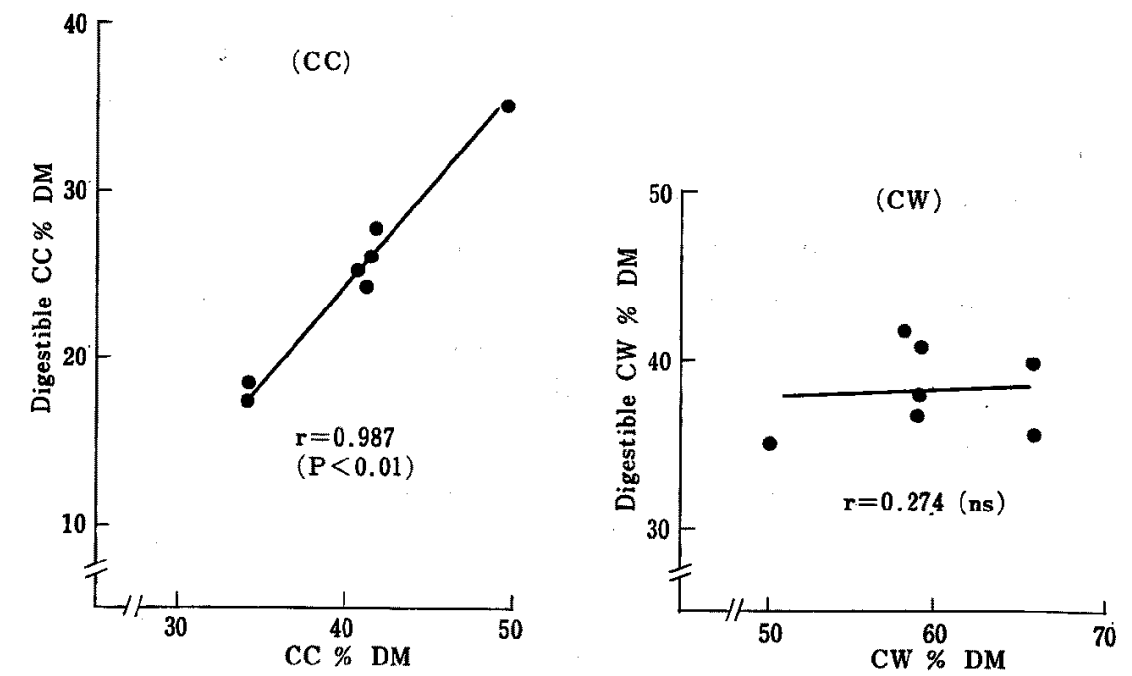

Fig. 3. Relationships between the total amounts and the quantities of digestible portion in $\mathrm{CC}$ and $\mathrm{CW}$. 

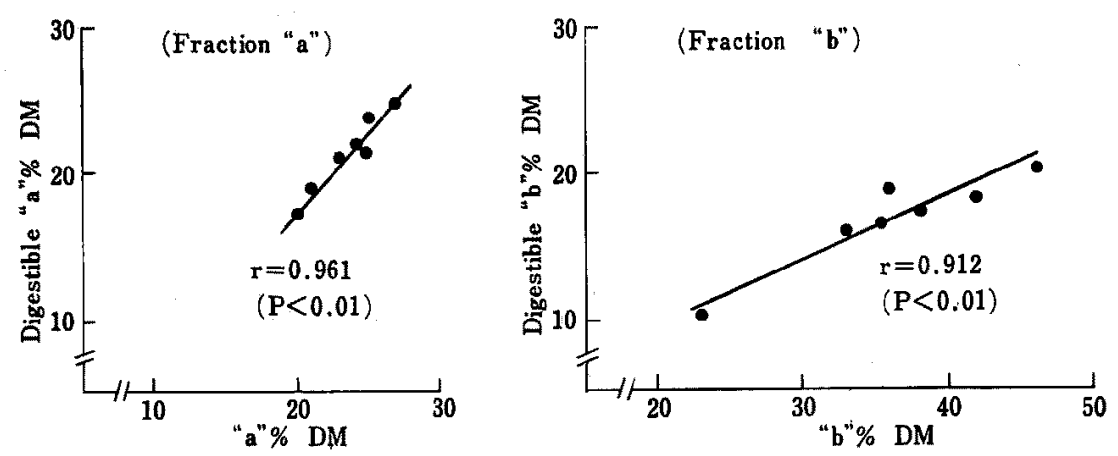

Fig. 4. Relationships between the total amounts and the quantities of digestible portion in Fraction " $a$ " and " $b$ ".

digestible portion for $\mathrm{CC}, \mathrm{CW}$, fraction "a" and fraction " $\mathrm{b}$ ", respectively. There was highly significant correlation between the amount of $\mathrm{CC}$ and that of digestible $\mathrm{CC}$, and this tendency was also in agreement with the results of VAN SOEST". There was no significant correlation with $\mathrm{CW}$, however, with both fraction " $\mathrm{a}$ " and " $\mathrm{b}$ ", highly significant correlations $(\mathrm{P}<0.01)$ were obtained.

From these results, it is clear that $\mathrm{CW}$ as a total is nonuniform fraction, but by cellulase analysis, CW of orchardgrass hay can be divided into two fractions which is nutritionally more uniform than total $\mathrm{CW}$. Structural carbohydrates of $\mathrm{CW}$ is the mixture of cellulose and hemicellulose which are different in crystallinity or degree of lignification in various samples, and $\mathrm{CW}$ digestibility is remarkably dominated by the degree of crystallinity or lignification. As above mentioned, concept of crystallinity or lignification of cell wall can say in other words, such as fraction " $a$ " and fraction " $b$ ". $\mathrm{CW}$ is the mixture of two fraction (" $\mathrm{a}$ " and " $\mathrm{b}$ ") which are extremely different in digestibilities and the proportion of fraction "a" and " $b$ " in CW is different in various samples. But within same fraction, both fraction " $a$ " and " $b$ " showed similar digestibilities, respectively. It is considered that similarity of the digestibility may support apparently the characteristics of nutritive uniformity of fraction " $a$ " and " $b$ ".

The author is grateful to Dr. K. Kameoka and Dr. Y. OHyama for reading this manuscript, and is also very grateful to Mr. NaKuI and Mr. IWASAKI for their help in preparation of hays and digestion trials.

\section{References}

1) ABE, A. and S. HoriI, J. Japan Grassl. Sci., 20: 16-21. 1974.

2) Yahata, S., T. NakuI, K. Iwasaki and A. ABE, Jap. J. Zootech. Sci., 44: 559-563. 1973.

3) Van Soest P. J., J. A. O. A. C., 50: 50-55. 1967.

4) Van Soest P. J., J. A. O. A.C., 46: 829-835. 1963.

5) HoriI, S. and A. ABE. Bull. Nat. Inst. Anim. Ind., 25: 63-68. 1972. 
6) Nakur, T., K. Iwasaki, M. Hayakawa and S. Yahata, Bull. Hokkaido Agr. Exp. St., 111: 79-90. 1975.

7) Van Soest P. J., J. Anim. Sci., 26: 119-128. 1967.

8) Morrison, I. M., Phytochem., 12: 2979-2984. 1973.

\section{オーチヤードグラスの生育によもなう消化率変化 \\ の解析を行なうための中性デタージェント・ \\ セルラーゼシステムの応用}

阿部亮

農林省畜産試験場，千葉市 280

中性デタージェント・セルラーゼのシステムを番草,

刚取時期の異なるオーチャードダラス乾草に通用し, 生 育にとむなう栄養洒の変化を解析した，まず，乾物は中 性デタージェントによって, Cellular Contents (CC) と Cell Wall (CW) とに分画され，次に $\mathrm{CW}$ は 1.0\%のセ ルラーゼ溶液で 4 時間加水分解されることによって，a， bという2つの領域に区分された. a の消化率の平均值

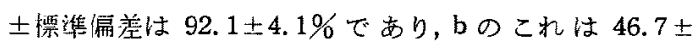
3.7\%であったbはそのリグニン化率が試料間で $\mathrm{CW}$ にくらべてかなり均質であり，しかも，乾物帆のグ二 ン令量とbの含量との間には $\mathrm{r}=0.948(\mathrm{P}<0.01) の$ 相関係数が得られた，一般的には，消化率の滈い $\mathrm{a}$ 分画 が生䏍にともなって減少し，逆にリダニン化領域と推定 さ机る消化率の低いb分画が增加する傾问を示したが， それは特に 1 番草において顕著であった，次に可消化量
について見ると, 乾物中の $\mathrm{a}, \mathrm{b}$ の含量と可消化 $\mathrm{a}, \mathrm{b}$ の 含量との間には，それぞれ， $\mathrm{r}=0.961,0.912$ の斯有 意 $(\mathrm{P}<0.01)$ の相関係数が認められた. この場合， $\mathrm{CW}$ について同様の処理を施しても，r=0.274 (n. s.) の值 しか得られなかった。つまり，栄養的に不均一と見なさ れる $\mathrm{CW}$ 分画は，より均一な $\mathrm{a}, \mathrm{b}$ という2つの領域に 分けら机るという事方解った. 可消化乾物 (DDM) z 可消化 CC (DCC) 之可消化 CW (DCW) の動きについ て見ると，7点の乾草で DCC の值の变動は DCW の值 の変動より大きく，そして，DDM と DCC, DCW との 間の相関係数を見ると，それぞれ，0.907 (P<0.01) と 0.174 (n.s.) の值を示し, DDM の変化は見かけじよ う，DCC の含量に左右されるという現象を示した。 日音会報，50(1)：28-34, 1979 